\title{
Healing of Periapical Lesions After Surgical Endodontic Retreatment: A Systematic Review
}

\author{
Faisal Alghamdi ${ }^{1}$, Abdulrahaman J. Alhaddad ${ }^{2}$, Samar Abuzinadah ${ }^{3}$ \\ 1. Oral Biology, King Abdulaziz University, Jeddah, SAU 2. Oral and Maxillofacial Rehabilitation, King Abdulaziz \\ University, Jeddah, SAU 3. Conservative Dentistry, King Abdulaziz University, Jeddah, SAU
}

Corresponding author: Faisal Alghamdi, dr.faisal2020@hotmail.com

\begin{abstract}
Background: Surgical root canal retreatment is required when peri-radicular pathosis associated with endodontically treated teeth cannot be treated by non-surgical root canal therapy (retreatment), or when retreatment was ineffective, not feasible or contraindicated. Endodontic failures maybe happen when irritants remain within the confines of the root canal, or when an extra-radicular infection cannot be eradicated by orthograde root canal treatment. Following enhanced microsurgical techniques in the last years, the success rates of surgical root canal retreatment have improved considerably.
\end{abstract}

Objective: The aim of this systematic review is to gather updated data in regard to the surgical root canal (retrograde) retreatment to heal the periapical lesions.

Materials and methods: The electronic databases PubMed and Google Scholar were searched in this review using specific inclusion and exclusion criteria. The search was performed in June 2019 and updated in November 2019. Among 3900 studies, 10 studies satisfied the eligibility criteria and were included in the review to be analyzed.

Results: The 10 studies showed the importance of surgical root canal retreatment as a treatment option in removing infections within the root canal system and its efficiency in periapical tissue healing. These studies investigated different aspects of healing of periapical lesion after surgical (retrograde) retreatment including success rates, follow-up duration, and updated studies in surgical (retrograde) retreatment.

Conclusions: Surgical root canal (retrograde) retreatment demonstrates its efficiency in reducing the period needed for healing of the periapical lesions in short-term follow-up compared to conventional orthograde retreatment.

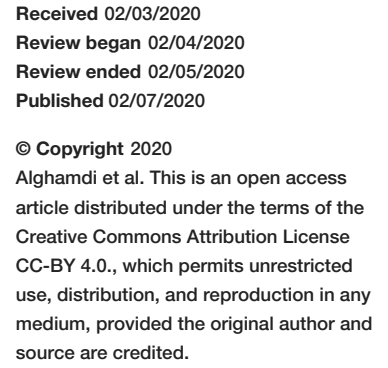
source are credited.
Categories: Pathology, Other, Dentistry

Keywords: healing, endodontic surgery, apical surgery, surgical retreatment, endodontic treatment, periapical lesion

\section{Introduction And Background}

Periapical lesions are one of the common pathological conditions affecting periradicular tissues [1]. The microbial invasion and subsequent infection of the canal systems of a root play a decisive role in the initiation and progression of periapical lesions [2]. Periapical lesions are mostly classified as radicular cysts, dental granulomas or abscesses [3,4]. Among all periapical lesions, the incidence of cysts varies from $6 \%$ to $55 \%$ [5]. Also, the occurrence of granulomas spans from $9.3 \%$ to $87.1 \%$, and of abscesses from $28.7 \%$ to $70.07 \%$ [6]. According to clinical evidence, lesions that are larger in size, are most likely radicular cysts. Still, some of these large lesions may appear to be granulomas [7].

The preliminary purpose of all endodontic procedures, especially cleaning and shaping, is to eliminate necrotic tissue and infective bacteria [8]. Large periapical lesions are of inflammatory origin as well as apical true cysts and should be treated initially with a nonsurgical approach [9]. When intra- or extra-radicular infections are persistent, and periapical pathology fails to resolve after nonsurgical endodontic management protocols, only then a surgical option should be considered [10]. Broad cross-sectional studies from various countries have stated that the prevalence of apical periodontitis and other post-treatment periradicular diseases can transcend $30 \%$ of all root-filled teeth population [11-14]. These facts recommend a significant requirement for the treatment of this condition [11-14]. Microsurgical endodontic treatment is better than conventional endodontic treatment and has high success rates [15].

There are several studies that were conducted to discuss the healing of periapical lesion after nonsurgical (orthograde) retreatment or surgical root canal treatment. However, few studies have investigated the healing of periapical lesion after surgical (retrograde) retreatment. Consequently, the aim of this review was to collect all updated and available studies including imperative information concerning the surgical root canal (retrograde) retreatment to heal periapical lesions. 


\section{Review}

\section{Material and methods}

This review has been compiled according to the Preferred Reporting Items for Systematic Reviews and Metaanalyses (PRISMA) guidelines.

\section{Research Question}

The following was the research question for the systematic review: "The best endodontic treatment option for the healing of periapical lesions: is it surgical retrograde retreatment or conventional orthograde retreatment?".

\section{Literature Search}

With respect to the question of the study, we searched the literature and identified relevant studies. The literature search was formulated in June 2019 and then updated in November 2019. A web search was done through PubMed (2009-2019) and Google Scholar (2009-2019) with MesH terms and/or in various combinations ("healing", "periapical lesion", "surgical root canal retreatment OR surgical endodontic retreatment", "endodontic microsurgery retreatment").

Relevant articles had been read and assessed by the introduction of the close meaning ideas by the study reviewers. Full articles were obtained for most of the titles and abstracts that met the inclusion criteria, the full text was accessed. From each included article, study design, interventions, and findings were extracted. Articles used were categorized into two main groups (free and restricted). Free ones have been downloaded directly by the URLs generated from the database. The restricted group has been downloaded by the institutional access of the King Abdulaziz University (KAU) library. Even though some articles did not match the main idea, they have been reviewed again \& decided to be either relevant or irrelevant.

\section{Inclusion Criteria}

1. Native research released in the English language.

2. Time framed articles released within 10 years (2009 - 2019).

3. Studies carried out on human subjects only.

\section{Exclusion Criteria}

1. Articles that described healing of periapical lesion with management techniques excluding the surgical root canal retreatment.

2. Articles that discussed healing of periapical lesion after surgical root canal retreatment by percentages and samples taken from animals.

3. Review articles.

\section{Critical Appraisal}

Eligible studies were independently analyzed by all reviewers according to the eligibility criteria as well as PRISMA guidelines. Any disagreement between the reviewers was resolved using discussion.

\section{Data Extraction and Presentation}

The search strategy using the keywords and MeSH of the databases like PUBMED and Google Scholar yielded a total of 3,900 studies, of which 3,580 were either unrelated or duplicate topics. Among the potential 140 studies, the eligibility criteria were applied and ten studies were included in this systematic review. The summary of the search flow chart for this systematic review has been depicted in (Figure 1). 


\section{Cureus}

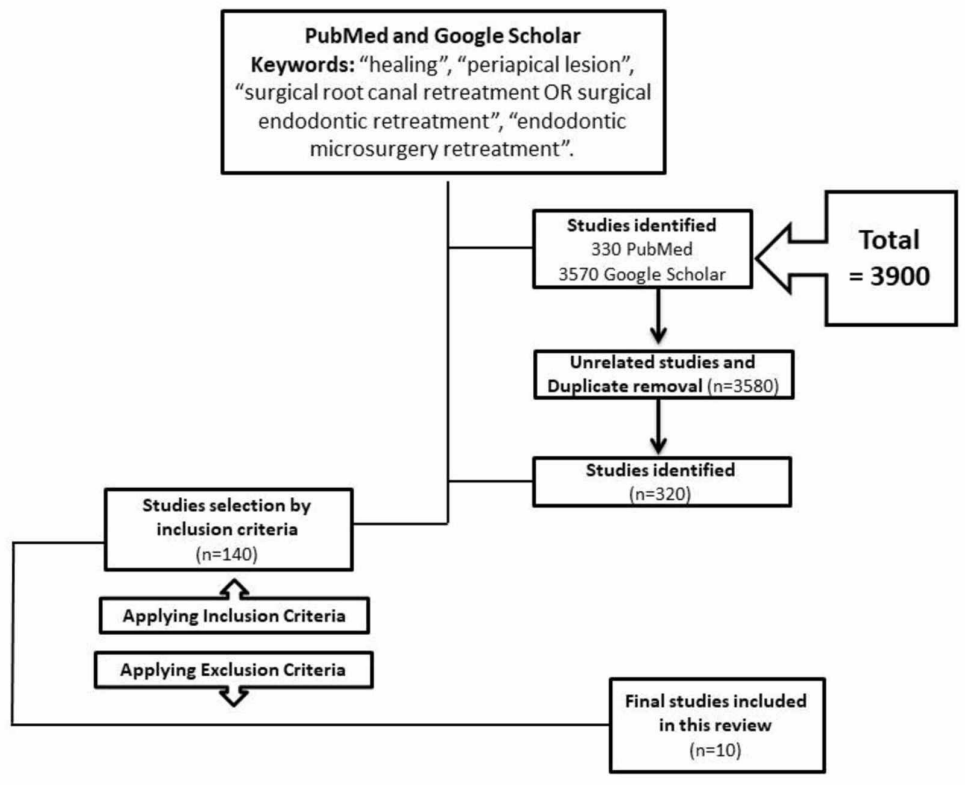

FIGURE 1: Flow Chart of the Search Strategy Used in this Systematic Review

\section{Results}

The search culminated in 10 studies that fulfilled both the inclusion and exclusion criteria and which were conducted in the last 10 years ago. These studies investigated the healing of periapical lesion after surgical root canal (retrograde) retreatment including success rates, follow-up duration, and updated studies in surgical root canal (retrograde) retreatment. The studies included in this systematic review were one randomized controlled trial study, two prospective studies, one retrospective study, and six case reports [1619,20-25]. The systematic review included ten studies with a total sample of 376 subjects that were treated from primary care centers and also universities outpatient departments of dental schools and hospitals. In all of the studies, the procedures were performed on systemically healthy persons. In regard to the duration of follow-up performed, one study ranged from 1 to 3 year recalls, four studies were performed with 1-year recall and different studies up to " 2 years recalls", " 5 year recalls", "6 year recalls", and "10 year recalls" [1625]. In regard to the surgical technique performed, the placement of root-end filling material was made in four studies, and in the other six studies, root-end filling material was not placed [16-25]. In regard to the effect on the healing of the periapical lesions, all the studies showed a high significant success rate of complete healed or remained healed of the periapical lesion after surgical retrograde retreatment [16-25]. In regard to the most success rate of endodontic surgery, two studies found that microsurgical techniques had a high success rate in healing the periapical lesions compared to conventional orthograde treatment $[23,24]$. All included studies were summarized in Table 1. A summary of all current systematic and meta-analysis reviews are summarized in Table 2 . 


\section{Cureus}

\begin{tabular}{|c|c|c|c|c|c|c|}
\hline $\begin{array}{l}\text { Authors/Study } \\
\text { Design }\end{array}$ & Year & $\begin{array}{l}\text { Number } \\
\text { of } \\
\text { Subjects }\end{array}$ & $\begin{array}{l}\text { Healing } \\
\text { (Yes / } \\
\text { No) }\end{array}$ & Duration of Follow-up & Main Results & Main Conclusion \\
\hline $\begin{array}{l}\text { Kruse C et al. } \\
{[16] \text {, Denmark, }} \\
\text { (Randomized } \\
\text { Controlled Trial } \\
\text { study) }\end{array}$ & 2016 & $(\mathrm{n}=44)$ & (Yes) & $\begin{array}{l}\text { "1 year" + "A 6-year } \\
\text { Follow-up". }\end{array}$ & $\begin{array}{l}\text { In the recall visit after } 6 \text { years, } 90 \% \text { of the teeth in the GP group } \\
\text { that were scored as effectively recuperated } 12 \text {-months } \\
\text { postoperatively stayed asymptomatic. In the MTA group, } 80 \% \text { of } \\
\text { the teeth studied as adequately repaired following } 12 \text {-months } \\
\text { stayed asymptomatic. }\end{array}$ & $\begin{array}{l}\text { Revelations demonstrate that a 12-months follow-up may not be } \\
\text { adequate in evaluating the long-term result of surgical endodontic } \\
\text { retreatment. With an extended follow-up, different determinants not } \\
\text { clearly associated with the endodontic treatment might be appropriate for } \\
\text { an effective result. }\end{array}$ \\
\hline $\begin{array}{l}\text { Shinbori N et al. } \\
\text { [19], USA, } \\
\text { (Retrospective } \\
\text { study) }\end{array}$ & 2015 & $(n=94)$ & (Yes) & $\begin{array}{l}\text { "Ranged from } 1 \text { to } 3 \\
\text { years". }\end{array}$ & $\begin{array}{l}\text { All-inclusive the success rate was } 92.0 \% \text { after the endodontic } \\
\text { microsurgery. }\end{array}$ & $\begin{array}{l}\text { The use of ES-BCRR as a root canal filling material resulted in a favorable } \\
\text { repair rate of } 92.0 \% \text { in endodontic microsurgery at least 12-months recall } \\
\text { investigation. }\end{array}$ \\
\hline $\begin{array}{l}\text { Machado R et } \\
\text { al. [20], Brazil, } \\
\text { (Case Report) }\end{array}$ & 2014 & $\begin{array}{l}\text { Two } \\
\text { Case } \\
\text { Report }\end{array}$ & (Yes) & $\begin{array}{l}\text { Case No.1: "9 months" + } \\
\text { "1-year follow-up". Case } \\
\text { No. 2: "Follow-up } \\
\text { examinations every } 3 \\
\text { months for a year". }\end{array}$ & $\begin{array}{l}\text { In the current cases, the outcome of the microsurgical techniques } \\
\text { in lesion regression and tooth survival } 1 \text { year post-treatment. }\end{array}$ & $\begin{array}{l}\text { It fortifies the statute that combining finding out about the biologic } \\
\text { aspects of endodontics with surgical endodontic treatment using a } \\
\text { modern technique is an elective foreseen treatment. }\end{array}$ \\
\hline $\begin{array}{l}\text { PFE Bernabe et } \\
\text { al. [21], Brazil, } \\
\text { (Case Report) }\end{array}$ & 2013 & $\begin{array}{l}\text { Case } \\
\text { Report }\end{array}$ & (Yes) & "A 5-year Follow-up" & $\begin{array}{l}\text { At the 5-year follow-up, there were no clinical signs or symptoms } \\
\text { related to the lesion, and the radiographic examination indicated a } \\
\text { growing resolution of the radiolucency. }\end{array}$ & $\begin{array}{l}\text { It might be presumed that MTA presents favorable qualities in unfavorable } \\
\text { conditions and could be used in combination with GTR in cases including } \\
\text { root reconstruction. }\end{array}$ \\
\hline $\begin{array}{l}\text { Song M et al. } \\
\text { [17], South } \\
\text { Korea, } \\
\text { (Prospective } \\
\text { Follow-up } \\
\text { study) }\end{array}$ & 2012 & $(n=172)$ & (Yes) & $\begin{array}{l}\text { "Followed up every } 6 \\
\text { months for } 24 \text { months } \\
\text { and every year up to } 10 \\
\text { years". }\end{array}$ & $\begin{array}{l}\text { Of the } 104 \text { followed-up cases, the successful group had } 97 \text { cases, } \\
91 \text { of which had complete healing and } 6 \text { had incomplete healing. } \\
\text { The general maintained success rate was } 93.3 \% \text {. }\end{array}$ & $\begin{array}{l}\text { In a previous 5-year study, } 93.3 \% \text { of endodontic microsurgery cases that } \\
\text { were considered successfully treated stayed the same after more than } 6 \\
\text { years. }\end{array}$ \\
\hline $\begin{array}{l}\text { Brito-Junior M } \\
\text { et al. [22], } \\
\text { Brazil, (Case } \\
\text { Report) }\end{array}$ & 2012 & $\begin{array}{l}\text { Case } \\
\text { Report }\end{array}$ & (Yes) & $\begin{array}{l}\text { "6 months" + "1 year" + } \\
\text { "2 year follows-up" }\end{array}$ & $\begin{array}{l}\text { A radiograph was taken following a half year exhibited progressed } \\
\text { periapical healing in the current case. Be that as it may, a complete } \\
\text { repair was noted at only one year postsurgery, and complete } \\
\text { periapical repair at the two-year follow-up. }\end{array}$ & $\begin{array}{l}\text { Based on these clinical and radiographic aspects, the apical surgical } \\
\text { intervention proved to be a successful treatment to overcome the failure } \\
\text { of the conservative approach used in this case. }\end{array}$ \\
\hline $\begin{array}{l}\text { Kahler B. [23], } \\
\text { Australia, (Case } \\
\text { Report) }\end{array}$ & 2011 & $\begin{array}{l}\text { Case } \\
\text { Report }\end{array}$ & (Yes) & "1-year follow-up" & Healing was evident at a 1-year review appointment. & $\begin{array}{l}\text { The overall healing of periapical lesions demonstrated superior results } \\
\text { when treated with microsurgery contrasted with conventional techniques } \\
\text { to endodontic surgery. Success rates have appeared to be comparable } \\
\text { with traditional orthograde treatment. }\end{array}$ \\
\hline $\begin{array}{l}\text { Song M et al. } \\
\text { [18], South } \\
\text { Korea, } \\
\text { (Prospective } \\
\text { Clinical study) }\end{array}$ & 2011 & $(n=54)$ & (Yes) & $\begin{array}{l}\text { "Every } 6 \text { months for } 2 \\
\text { succeeding and Every } \\
\text { year" }\end{array}$ & $\begin{array}{l}42 \text { cases were recalled, } 39 \text { of which were included in the success } \\
\text { category, giving an overall success rate of } 92.9 \% \text {. }\end{array}$ & $\begin{array}{l}\text { The use of microsurgical techniques and biocompatible materials such as } \\
\text { MTA and Super-EBA outcomed in a high clinical success rate, even in } \\
\text { endodontic re-surgery. }\end{array}$ \\
\hline $\begin{array}{l}\text { Kahler B [24], } \\
\text { Australia, (Case } \\
\text { Report) }\end{array}$ & 2010 & $\begin{array}{l}\text { Case } \\
\text { Reports }\end{array}$ & (Yes) & "1 year follow-up" & $\begin{array}{l}\text { Healing was obvious at 12-month recall. Microsurgical techniques } \\
\text { have significantly improved the results for healing of periapical } \\
\text { lesions when contrasted with traditional approaches to endodontic } \\
\text { surgery. }\end{array}$ & $\begin{array}{l}\text { Success rates were found to be comparable with conventional orthograde } \\
\text { treatment. }\end{array}$ \\
\hline $\begin{array}{l}\text { Karabucak B et } \\
\text { al. [25] USA, } \\
\text { (Case Report) }\end{array}$ & 2009 & $\begin{array}{l}\text { Two } \\
\text { Case } \\
\text { Reports }\end{array}$ & (Yes) & $\begin{array}{l}\text { Case No.1: "One-year and } \\
\text { 2-year recalls". Case } \\
\text { No.2: "At a 1-year recall". }\end{array}$ & $\begin{array}{l}\text { Case No.1: Radiographic assessments showed complete periapical } \\
\text { bone healing when microsurgery was utilized. Case No.2: Normal } \\
\text { results were found for clinical and radiographic examinations. }\end{array}$ & lese cases show successful surgical treatment of combined lesions. \\
\hline
\end{tabular}

TABLE 1: Summary of All Included Studies in the Systematic Review 


\section{Cureus}

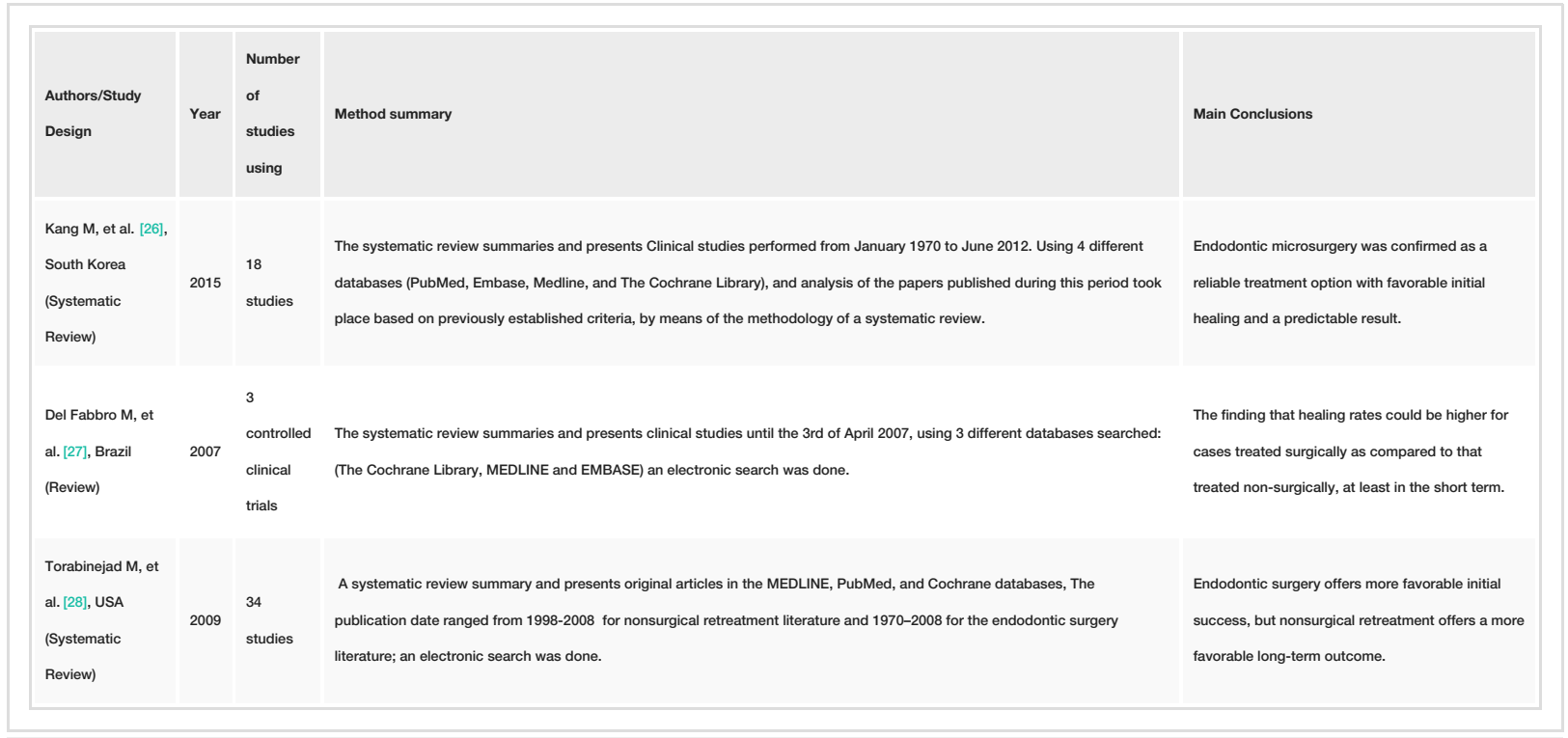

TABLE 2: Summary of All Current Systematic and Meta-analysis Reviews in the Literature

\section{Discussion}

The systematic review presents a comprehensive compilation of evidence taken from ten articles which included original studies. The sample size was up to 376 subjects seeking endodontic retreatment by the use of surgical retrograde retreatment. All included studies confirmed faster treatment time by surgical root canal (retrograde) retreatment (Table 1). The recently published systematic reviews by Kang M et al. in 2015 illustrated "The endodontic microsurgery and nonsurgical retreatment have stable results showing the overcome of pooled success rates at about $92 \%$ and around $80 \%$, respectively" (Table 2) [26]. When the data were reviewed and analyzed in the follow-up periods, they found the microsurgery group had a significantly superior success rate than the retreatment group in the short-term follow-up, while no significant difference was improved in the long-term follow-up [26].

Also, Del Fabbro et al. in 2007 and Torabinejad et al. in 2009 have compared the success rates of non-surgical orthograde and surgical retrograde endodontic retreatment $[27,28]$. They found the surgically treated cases seem to indicate a higher success rate after one year. However, after 2-4 years relative success rates show equivalent or reversed $[27,28]$. This clearly shows agreement in the conclusions reached by these systematic/meta-analysis reviews in regards to the healing of periapical lesions by surgical retrograde retreatment compared to the conventional orthograde retreatment especially after one year of procedure (short-term follow-up). When examining our included studies individually, 10 studies favored the use of surgical root canal (retrograde) retreatment, whereas most of the studies concluded that there was a high significant success rate of complete healed or remained healed of periapical lesions after the (retrograde) retreatment in short-term follow-up, but there are some studies showed significant healing of periapical lesions after different long-term follow-ups [16-25]. In addition, two studies found that microsurgical techniques have a high success rate in healing of the periapical lesions compared to conventional orthograde treatment $[23,24]$. Our results clearly reveal the controversy in the literature; however, there is, indeed, a strong trend toward supporting the microsurgical retreatment. Hence, more studies are needed to formulate the proper guidelines and parameters of how and when surgical retrograde retreatment can be used and considered as an accurate and reliable treatment option to heal the periapical lesions.

\section{Conclusions}

Surgical root canal (retrograde) retreatment is defined as an important invasive procedure that permits fast treatment options minus the necessity of the extensive traditional method. Surgical retrograde retreatment demonstrates its efficiency in reducing the period needed for healing of the periapical lesions and suggests benefits that will result in better recognition among patients seeking faster results in short-term follow-up, but on the long-term follow-up showed not significant difference for healing of periapical lesions compared to conventional orthograde retreatment. However, more clinical trials are encouraged to inspect the results of surgical retrograde retreatment on the healing of periapical lesions.

\section{Additional Information \\ Disclosures}

Conflicts of interest: In compliance with the ICMJE uniform disclosure form, all authors declare the 
following: Payment/services info: All authors have declared that no financial support was received from any organization for the submitted work. Financial relationships: All authors have declared that they have no financial relationships at present or within the previous three years with any organizations that might have an interest in the submitted work. Other relationships: All authors have declared that there are no other relationships or activities that could appear to have influenced the submitted work.

\section{References}

1. Karunakaran JV, Abraham CS, Karthik AK, Jayaprakash N: Successful nonsurgical management of periapical lesions of endodontic origin: a conservative orthograde approach. J Pharm Bioallied Sci. 2017, 9:246-251. 10.4103/jpbs.JPBS_100_17

2. Croitoru IC, CraiToiu S, Petcu CM, et al.: Clinical, imagistic and histopathological study of chronic apical periodontitis. Rom J Morphol Embryol. 2016, 57:719-728.

3. Lalonde ER, Luebke RG: The frequency and distribution of periapical cysts and granulomas: an evaluation of 800 specimens. Oral Surg Oral Med Oral Pathol. 1968, 25:861-8. 10.1016/0030-4220(68)90163-1

4. Shteyer A, Rozovsky E: Periapical lesions--types, incidence and clinical features . Refuat Hapeh Vehashinayim. 1972, 21:100-3.

5. Nair PNR, Pajarola G, Schroeder HE: Types and incidence of human periapical lesions obtained with extracted teeth. Oral Surg Oral Med Oral Pathol Oral Radiol Endod. 1996, 81:93-102.

6. Schulz M, T von Arx, Altermatt HJ, Bosshardt D: Histology of periapical lesions obtained during apical surgery. J Endod. 2009, 35:634-42. 10.1016/j.joen.2009.01.024

7. Natkin E, Oswald RJ, Carnes LI: The relationship of lesion size to diagnosis, incidence, and treatment of periapical cysts and granulomas. Oral Surg Oral Med Oral Pathol. 1984, 57:82-94. 10.1016/00304220(84)90267-6

8. Abbott PV: The periapical space--a dynamic interface . Aust Endod J. 2002, 28:96-107. 10.1111/j.17474477.2002.tb00399.x

9. Santos Soares SM, Brito-Junior M, de Souza FK, et al.: Management of cyst-like periapical lesions by orthograde decompression and long-term calcium hydroxide/chlorhexidine intracanal dressing: a case series. J Endod. 2016, 42:1135-41. 10.1016/j.joen.2016.04.021

10. Lin LM, Ricucci D, Lin J, Rosenberg PA: Nonsurgical root canal therapy of large cyst-like inflammatory periapical lesions and inflammatory apical cysts. J Endod. 2009, 35:607-15. 10.1016/j.joen.2009.02.012

11. Boucher Y, Matossian L, Rilliard F, Machtou P: Radiographic evaluation of the prevalence and technical quality of root canal treatment in a French subpopulation. Int Endod J. 2002, 35:229-238. 10.1046/j.13652591.2002.00469.x

12. Dugas NN, Lawrence HP, Teplitsky PE, et al.: Periapical health and treatment quality assessment of rootfilled teeth in two Canadian populations. Int Endod J. 2003, 36:181-92.

13. Eriksen HM, Kirkevang LL, Petersson K: Endodontic epidemiology and treatment outcome: general considerations. Endod Topics. 2002, 2:1-9. 10.1034/j.1601-1546.2002.20101.x

14. Friedman S: Considerations and concepts of case selection in the management of post-treatment endodontic disease (treatment failure). Endod Topics. 2002, 1:54-78. 10.1034/j.1601-1546.2002.10105.x

15. Torabinejad M, White SN: Endodontic treatment options after unsuccessful initial root canal treatment: alternatives to single-tooth implants. J Am Dent Assoc. 2016, 147:214-20. 10.1016/j.adaj.2015.11.017

16. Kruse C, Spin-Neto R, Christiansen R, Wenzel A, Kirkevang LL: Periapical bone healing after apicectomy with and without retrograde root filling with mineral trioxide aggregate: a 6-year follow-up of a randomized controlled trial. J Endod. 2016, 42:533-7. 10.1016/j.joen.2016.01.011

17. Song M, Chung W, Lee SI, Kim E: Long-term outcome of the cases classified as successes based on shortterm follow-up in endodontic microsurgery. J Endod. 2012, 38:1192-6. 10.1016/j.joen.2012.06.014

18. Song M, Shin SJ, Kim E: Outcomes of endodontic micro-resurgery: a prospective clinical study . J Endod. 2011, 37:316-20. 10.1016/j.joen.2010.11.029

19. Shinbori N, Grama AM, Patel Y, et al.: Clinical outcome of endodontic microsurgery that uses EndoSequence BC root repair material as the root-end filling material. J Endod. 2015, 41:607-12. 10.1016/j.joen.2014.12.028

20. Machado R, Vansan LP, da Cruz AM, da Silva EJN: Surgical endodontic reintervention using a modern technique: 2 case reports. Gen Dent. 2014, 62:40-3.

21. Bernabe PF, Azuma MM, Ferreira LL, Dezan-Júnior E, Gomes-Filho JE, Cintra LTA: Root reconstructed with mineral trioxide aggregate and guided tissue regeneration in apical surgery: a 5-year follow-up. Braz Dent J. 2013, 24:428-32. 10.1590/0103-6440201302242

22. Brito-Junior M, Faria-e-Silva AL, Quintino AC, Moreira-Junior G, Geber M, Camilo CC, Soares JA: Orthograde retreatment failure with extruded MTA apical plug in a large periradicular lesion followed by surgical intervention: case report. Gen Dent. 2012, 60:96-100.

23. Kahler B: Microsurgical endodontic retreatment of a maxillary molar with a separated file: a case report . Aust Dent J. 2011, 56:76-81. 10.1111/j.1834-7819.2010.01281.x

24. Kahler B: Microsurgical endodontic retreatment of post restored posterior teeth: a case series . Aust Endod J. 2010, 36:114-21. 10.1111/j.1747-4477.2010.00277.x

25. Karabucak B, Setzer FC: Conventional and surgical retreatment of complex periradicular lesions with periodontal involvement. J Endod. 2009, 35:1310-5. 10.1016/j.joen.2009.05.007

26. Kang M, In Jung H, Song M, Kim SY, Kim HC, Kim E: Outcome of nonsurgical retreatment and endodontic microsurgery: a meta-analysis. Clin Oral Investig. 2015, 19:569-82. 10.1007/s00784-015-1398-3

27. Del Fabbro M, Taschieri S, Testori T, Francetti L, Weinstein RL: Surgical versus non-surgical endodontic retreatment for periradicular lesions. Cochrane Database Syst Rev. 2007, 10.1002/14651858.CD005511.pub2

28. Torabinejad M, Corr R, Handysides R, Shabahang S: Outcomes of nonsurgical retreatment and endodontic surgery: a systematic review. J Endod. 2009, 35:930-7. 10.1016/j.joen.2009.04.023 